\title{
A lack of freshwater reservoir effects in human radiocarbon dates in the Eneolithic to Iron Age in the Minusinsk Basin
}

\author{
Svetlana V. Svyatko ${ }^{1} \cdot$ Rick Schulting $^{2} \cdot$ Andrey Poliakov $^{3} \cdot$ Neil Ogle $^{4}$. \\ Paula J. Reimer ${ }^{1}$
}

Received: 31 March 2016 / Accepted: 5 September 2016 / Published online: 29 October 2016

(C) The Author(s) 2016. This article is published with open access at Springerlink.com

\begin{abstract}
A number of recent studies have highlighted the importance of freshwater reservoir effects (FRE) when dating human remains across large parts of Eurasia, including the Eurasian steppes. Here, we address this question in the context of the Early Bronze Age (Okunevo), Late Bronze Age (Karasuk) and Late Iron Age (Tashtyk culture) of the Minusinsk Basin, Southern Siberia. The issue is important given the large number of radiocarbon dates that have been published on human remains here, which have been used both to refine the cultural historical sequence (Svyatko et al. 2009), as well as to suggest a date of ca. $1400 \mathrm{BC}$ for the appearance of millet agriculture (Svyatko et al. 2013). In these studies, it was argued that there was little or no freshwater reservoir effect to take into account, despite the likely consumption of freshwater fish. Subsequent work across the steppe raised a legitimate question concerning this assumption. Here, we present the first set of paired dates on late prehistoric humans and terrestrial fauna from the Minusinsk Basin, as well as data from modern fish for the region. The results, with one exception, show no clear evidence for a reservoir effect, with the human-fauna difference averaging $-31 \pm 95{ }^{14} \mathrm{C}$ years. Yet,
\end{abstract}

Svetlana V. Svyatko

s.svyatko@qub.ac.uk

${ }^{1}{ }^{14}$ CHRONO Centre for Climate, the Environment, and Chronology, Queen's University of Belfast, Belfast, Northern Ireland BT7 1NN, UK

2 School of Archaeology, University of Oxford, 36 Beaumont Street, Oxford, England OX1 2PG, UK

3 Institute for the History of the Material Culture, Russian Academy of Sciences, 18 Dvortsovaya nab., St Petersburg 191186, Russia

4 Stable Isotope Facility, School of Natural and Built Environment, The Queen's University of Belfast, Belfast, Northern Ireland BT9 $5 \mathrm{AG}, \mathrm{UK}$ dating of modern fish from the Yenisei River and its tributary Karasuk River does show a variable but significant FRE. Either this effect has changed radically over time, or the contribution of fish to human diets in the Minusinsk Basin was less than previously thought.

Keywords Freshwater reservoir effects - Eurasian Steppe Minusinsk Basin · Okunevo · Karasuk · Tashtyk · Carbon · Nitrogen and sulphur isotope analysis

\section{Introduction}

The Minusinsk Basin of Southern Siberia represents one of the most explored regions in Siberia and in the Eurasian Steppe in terms of radiocarbon chronologies and palaeodietary isotopic analysis of Eneolithic to Early Iron Age populations. The large set of ${ }^{14} \mathrm{C}$ dates from human remains (more than 100) obtained for the region to date has been used both to refine the cultural historical sequence (Svyatko et al. 2009), as well as to suggest a date of ca. $1400 \mathrm{BC}$ for the appearance of millet as an important element of human diet (ibid.). In these studies, it was argued that there was little or no freshwater reservoir effect (FRE) to take into account, despite the likely consumption of freshwater fish by humans. No solid evidence for absence of the FRE in the region was available at that time, and the assumption of little or no FRE was made based on the lack of relationship between the ${ }^{14} \mathrm{C}$ age of humans and their $\delta^{15} \mathrm{~N}$ values. Subsequent work across the steppe raised a legitimate concern regarding this assumption, and hence, the reliability of existing radiocarbon dates from human bones and chronologies based on them.

Here, we present new evidence for the extent of modern freshwater reservoir effects in the Minusinsk Basin, as well as the first attempt to assess the influence of the FRE on 
archaeological human remains from the region through paired accelerator mass spectrometry (AMS) ${ }^{14} \mathrm{C}$ dates from late prehistoric humans and associated terrestrial fauna from the same burial contexts.

\section{The FRE in Eurasia}

Recently, a number of studies have been focused on the variability of freshwater reservoir effects and their effect on chronology of the prehistoric populations and events. The FRE occurs when part of the carbon in an individual's diet comes from a freshwater source with a lower-than-atmospheric ${ }^{14} \mathrm{C}$ concentration, and this results in an offset (i.e. "older") ${ }^{14} \mathrm{C}$ age for such a sample compared to ${ }^{14} \mathrm{C}$ age of a contemporaneous purely terrestrial sample. One source of "old" carbon in freshwater is dissolved inorganic carbon from ${ }^{14} \mathrm{C}$-free carbonate minerals in groundwater (e.g. Godwin 1951; Deevey et al. 1954; Sveinbjörnsdóttir et al. 1995; Culleton, 2006). In the process of underwater photosynthesis, this carbon becomes incorporated into aquatic plants and algae, and is then transferred further up the food chain to aquatic fauna and terrestrial animals (including humans) that rely on aquatic sources. Freshwater reservoir offsets (FRO) can be highly variable within the reservoir depending on the type and age of the organism analysed, which is related to its particular habitat and diet (e.g. Fernandes et al. 2013). For example, because of greater carbon exchange between the atmosphere and the water, fish and shellfish living in shallow or wellmixed water will be affected by FRE to a lesser extent than bottom feeders in deep water. The FRE can also vary through time as a result of changes in the hydrological system (e.g. Ascough et al. 2010) or the reservoir or, presumably, climatic conditions, leading to the thawing of permafrost and the entry of "old" organic carbon into local reservoirs (see discussion in Schulting et al. 2015). The latter could be a factor in the Minusinsk Basin, as permafrost is present in Western and Eastern Sayan mountains, surrounding the depression.

The majority of FRE research has focussed on Europe (Cook et al. 2001, 2002; Fischer and Heinemeier 2003; Olsen et al. 2010; Keaveney and Reimer 2012; Lougheed et al. 2013; Fernandes et al. 2014; Meadows et al. 2016) and North America (Ingram and Southon 1996; Goodfriend and Flessa 1997; Culleton 2006), and only recently has the importance of freshwater reservoir effects been highlighted for Russia and the Eurasian steppe zone, including the upper Lena River and Lake Baikal region (Nomokonova et al. 2013; Schulting et al. 2014, 2015), Caspian steppes and lower Don River (Shishlina et al. 2007, 2009, 2012, 2014; Motuzaite-Matuzeviciute et al. 2015), middle and lower reaches of the Dnieper River (Lillie et al. 2009), NorthEastern Kazakhstan (Svyatko et al. 2015), Sertejka River in Smolensk Oblast (Kulkova et al. 2015) and Kubenskoye Lake in Vologda Oblast (Wood et al. 2013). The main finding from this research is that freshwater reservoir effects are extremely variable geographically (spanning from zero to several thousand years), and that when dealing with archaeological human remains "each population thought to be affected by a FRE must be examined individually" (Wood et al. 2013, p. 163). Here, we apply this admonition to the Late Bronze and Iron Age populations of the Minusinsk Basin.

\section{The Minusinsk Basin}

The Middle Yenisei River region represents a group of isolated intermountain basins surrounded by the Kuznetsk Alatau mountain range, and by the Western and Eastern Sayan mountains. The combination of a rich hydrological system, vast steppes and climatic conditions are virtually ideal for stock rearing which became the basis of the economy for the ancient populations in the area from the Eneolithic, supported by hunting and fishing (Vadetskaya 1986).

Funerary sites prevail in the archaeology of the Middle Yenisei; this possibly explains the absence of remains associated with fishing. The clear exception are the sites of the Okunevo culture (twenty-fifth to eighteenth century BC) which have yielded tools associated with fishing (spears, needles for making nets, stone sinkers and fishing hooks; Vadetskaya et al. 1980; Lazaretov 1997; Kovalev 1997; Gotlib and Podolsky 2008) hinting at the possibility of an important role for fishing in the economy. No fishing tools have been found in the Karasuk (thirteenth to ninth century $\mathrm{BC}$ ) and Tashtyk (first to sixth century $\mathrm{AD}$ ) sites which may be explained by the absence of the tradition of offering utilitarian tools as grave goods (e.g. Vadetskaya 1986). Fish remains have only been recovered from one Karasuk and one Tashtyk site (Vadetskaya and Poselyanin 2015).

\section{Materials and methods}

\section{Materials}

In total, four modern fish from two sites and five groups of associated archaeological samples $(n=14)$ from four sites have been analysed, including six humans, five animals, and three wood samples (Tables 1, 2).

Archaeological materials were collected from the following sites (Fig. 1):

1. Uibat-Charkov (excavations by I. P. Lazaretov, 2009)an Okunevo culture (middle of third - first half of second mil. BC) cemetery which consists of three kurgans located $1 \mathrm{~km}$ NW from Charkov village (Ust-Abakanskiy region, Khakassia Republic), on a terrace above the Uibat River, in the piedmont of the Khazynsorakh mountains. Kurgan 1 contained 16 Okunevo and one Tashtyk grave. Okunevo grave 11 was located in the SW sector and contained the 
Table 1 Results of AMS ${ }^{14} \mathrm{C}$ dating, stable $\mathrm{C}$ and $\mathrm{N}$ isotope analysis and calculated freshwater reservoir offsets (FRO) for modern fish

\begin{tabular}{|c|c|c|c|c|c|c|c|c|c|}
\hline Lab ID & Species & Provenance & $\%$ coll. & $\mathrm{F}^{14} \mathrm{C} \pm \sigma \mathrm{F}^{14} \mathrm{C}$ & FRO $\left({ }^{14} \mathrm{C}\right.$ years $)$ & $\mathrm{C} / \mathrm{N}_{\mathrm{at}}$ & $\delta^{13} \mathrm{C}$ & $\delta{ }^{15} \mathrm{~N}$ & $\delta^{34} \mathrm{~S}$ \\
\hline UBA-29395 & Adult pike (Esox lucius) & Karasuk Bay & 13.7 & $0.9614 \pm 0.0032$ & $757 \pm 31$ & 3.2 & -23.9 & 12.3 & -1.71 \\
\hline SS MBF-1 & & & $\mathrm{n} / \mathrm{a}$ & - & - & 3.2 & -23.2 & 12.4 & \\
\hline UBA-29396 & Small pike (Esox lucius) & Karasuk Bay & 9.1 & $0.976 \pm 0.0033$ & $636 \pm 31$ & 3.5 & -26.1 & 12.6 & 0.14 \\
\hline SS MBF-2 & & & $\mathrm{n} / \mathrm{a}$ & - & - & 3.3 & -25.3 & 14.9 & \\
\hline UBA-29397 & Carp (Cyprinus carpio) & Karasuk Bay & 19.9 & $1.0041 \pm 0.0032$ & $408 \pm 30$ & 3.1 & -24.2 & 8.9 & -3.91 \\
\hline SS MBF-3 & & & $\mathrm{n} / \mathrm{a}$ & - & - & 3.7 & -23.1 & 8.8 & \\
\hline UBA-29398 & Sazan (Cyprinus carpio) & Yenisei River & 13.1 & $1.0349 \pm 0.0033$ & $165 \pm 30$ & 3.2 & -25.3 & 9.3 & -2.59 \\
\hline SS MBF-4 & & & $\mathrm{n} / \mathrm{a}$ & - & - & 3.2 & -23.9 & 9.5 & \\
\hline
\end{tabular}

Note that fish samples underwent different pretreatment. For samples with lab IDs SS MBF, the $\delta^{15} \mathrm{~N}$ values were taken from the sample not subjected to lipid removal, and the $\delta^{13} \mathrm{C}$ value was obtained by taking the carbon isotopic value of the sample which had undergone the lipid removal process and adding $1.5 \%$ for the Suess effect (see Sample Pretreatment section for details)

$n / a$ not applicable

skeletons of a 30-year-old female (UBA-31076) and 1214-year-old male (UBA-31077), two pots, a stone scraper, 14 sheep astragali (UBA-31075), a bronze awl, and a white perforated stone ball. The wood from the burial structure has also been sampled (UBA-31074).

2. Krasniy Kamen (excavations by I. P. Lazaretov, 2010) represents two kurgans of Okunevo culture located $2 \mathrm{~km} \mathrm{~N}$ of Krasniy Kamen village (Bogradskiy region, Khakassia Republic), on the left slightly sloping terrace of the Koksa River, $500 \mathrm{~m}$ from its bed. Kurgan 1 contained 12 graves. Grave 1 is located in the very centre of the enclosure and it represents the first burial of the kurgan. The grave had been plundered, but the remaining finds show that the grave held the remains of a 20-25-year-old female (UBA-31072), interred with, at minimum, a ceramic pot, 37 perforated deer teeth (UBA-31073), a bone comb and 36 stone beads and one bone bead.

3. Tes 9 (excavations by O. V. Kovaleva, 2006) —a Karasuk culture (thirteenth to ninth century $\mathrm{BC}$ ) cemetery consisting of more than 500 kurgans located $3.5 \mathrm{~km} \mathrm{~W}$ from Tes village (Minusinsk region, Krasnoyarsk Krai), on the slope of Georgievskaya mountain in the valley of the Tuba River. Kurgan 50 is one of the largest, containing only one grave located in the very centre. The burial had been disturbed and it contained pottery fragments, human (45-50-year-old male, UBA-31311, and fragments of skull of another male apparently from a different grave) and animal (including cattle and sheep, UBA-31312) bones and a bronze temple ring.

4. Abakan 8 (excavations by P. B. Amzarakov, 2014 2015) - a multi-period cemetery located in a modern construction site in the central part of Abakan City. Kurgan 1 belongs to the Podgornovo phase (eighth to sixth century $\mathrm{BC})$ of the Tagar culture, and it contained an intrusive burial of the succeeding Tashtyk culture (first to fifth century $\mathrm{AD}$ ). As such, the kurgan held the remains of a disturbed intrusive burial (wood, human and faunal remains sampled, UBA-31078-31080), and disturbed original earth grave containing a mummified inhumation and three cremations. Excavation 5 represents an area of ca. $500 \mathrm{~m}^{2}$ in the central part of the construction site, encompassing a mainly nineteenth century cemetery and at least 32 prehistoric burials. Grave 30 represented a $2.85 \times 2 \mathrm{~m}$ timber burial orientated to the $\mathrm{W}$ covered with bark. The grave had been plundered and it contained two partially disarticulated inhumations with trepanned skulls (skeleton 1 has been sampled, UBA-31082), one cremation, three ceramic pots, bone awl, animal bones (UBA31083), golden foil and copper fragment. Wood from the burial structure has also been sampled (UBA-31081).

Notably, three of four analysed burials were disturbed. For the area of Minusinsk Basin, intact burials are generally very rare; however, in these cases, the association of human and faunal remains is considered to be reasonable.

Modern fish were collected from local fishermen in two locations, from the mouth of the Tuba River (Yenisei tributary) near Tepsei mountain (UBA-29398), and from the mouth of Karasuk River (Karasuk Bay, another tributary of Yenisei, UBA-29395-29397; Fig. 1). In all cases, the fish were cooked prior to sampling the bones (spine and ribs) for analysis. We do not expect this to have had a significant effect on the ${ }^{14} \mathrm{C}$ dates.

\section{Sample pretreatment}

Sample pretreatment was performed in the ${ }^{14} \mathrm{CHRONO}$ Centre for Climate, the Environment and Chronology (Queen's University Belfast). For bone samples, the surfaces were cleaned prior to collagen extraction. The extraction of collagen from archaeological samples was based on the ultrafiltration method (Brown et al. 1988; Bronk Ramsey et al. 
2004) with an additional sodium hydroxide $(\mathrm{NaOH})$ wash step (Brock et al. 2010). Briefly, these included the following:

(a) Bone demineralization in $2 \% \mathrm{HCl}$, followed by MilliQ® ultrapure water wash

(b) $0.1 \mathrm{M} \mathrm{NaOH}$ treatment for $15 \mathrm{~min}$ to remove humic acids, followed by MilliQ ${ }^{\circledR}$ wash

(c) $2 \% \mathrm{HCl}$ wash for $15 \mathrm{~min}$, followed by MilliQ® wash

(d) Gelatinization in $\mathrm{pH}=2 \mathrm{HCl}$ at $58^{\circ} \mathrm{C}$ for $16 \mathrm{~h}$

(e) Filtration, using ceramic filter holders, glass filter flasks and $1.2-\mu \mathrm{m}$ glass microfiber filters

(f) Ultrafiltration using Vivaspin ${ }^{\circledR} 15 \mathrm{~S}$ ultrafilters with MWCO $30 \mathrm{kDa} ; 3000-3500 \mathrm{rpm}$ for $30 \mathrm{~min}$ and

(g) Freeze-drying; the dried collagen was stored in a desiccator

Modern fish bones were pre-treated for stable isotope analysis and ${ }^{14} \mathrm{C}$ dating at different times. For this reason, the pretreatment procedure varied. For ${ }^{14} \mathrm{C}$ dating and sulphur isotopic measurements (lab IDs UBA), the procedure above was followed for pretreatment of modern fish bones, but omitting the $\mathrm{NaOH}$ step, as modern fish would not contain humic acids commonly affecting archaeological bones. For carbon and nitrogen stable isotope analysis (lab IDs SS MBF), two samples of collagen were prepared for each fish specimen so that the stable carbon $\left(\delta^{13} \mathrm{C}\right)$ and nitrogen $\left(\delta^{15} \mathrm{~N}\right)$ values could be measured separately. The first sample of each fish was subjected to the lipid removal process following Bligh and Dyer (1959), as lipids are significantly lower in ${ }^{13} \mathrm{C}$ and thus the measured signal will not correspond to that for protein (e.g. Liden et al. 1995; Sotiropoulos et al. 2004; Mintenbeck et al. 2008). Afterwards, the process of collagen extraction described above (excluding the $\mathrm{NaOH}$ step) was applied to all samples. The $\delta^{15} \mathrm{~N}$ values of the fish (introduced in Table 1 and Fig. 2) represent the sample not subjected to lipid removal, as this process is known to potentially alter nitrogen isotopic values (e.g. Sotiropoulos et al. 2004); the final $\delta^{13} \mathrm{C}$ values represent the sample which had undergone the lipid removal process plus $1.5 \%$ (as suggested by Tieszen and Fagre 1993) to offset for post-industrialisation changes in the atmospheric reservoir due to fossil fuel burning (the Suess effect).

Wood pretreatment follows the standard AAA procedure (Mook and Waterbolk 1985) and included $4 \% \mathrm{HCl}$ wash on an $80{ }^{\circ} \mathrm{C}$ hotplate for $2-3 \mathrm{~h}$ followed by $2 \% \mathrm{NaOH}$ wash for $2 \mathrm{~h}$, and then by another $4 \% \mathrm{HCl}$ wash on an $80^{\circ} \mathrm{C}$ hotplate for 2-3 $\mathrm{h}$.

\section{Stable isotope analysis and AMS radiocarbon dating}

Bone collagen stable carbon and nitrogen isotopes were measured in duplicate on a Thermo Delta V Isotope Ratio Mass Spectrometer (IRMS) coupled to a Thermo Flash 1112 Elemental Analyzer (EA) peripheral in the ${ }^{14} \mathrm{CHRONO}$ 


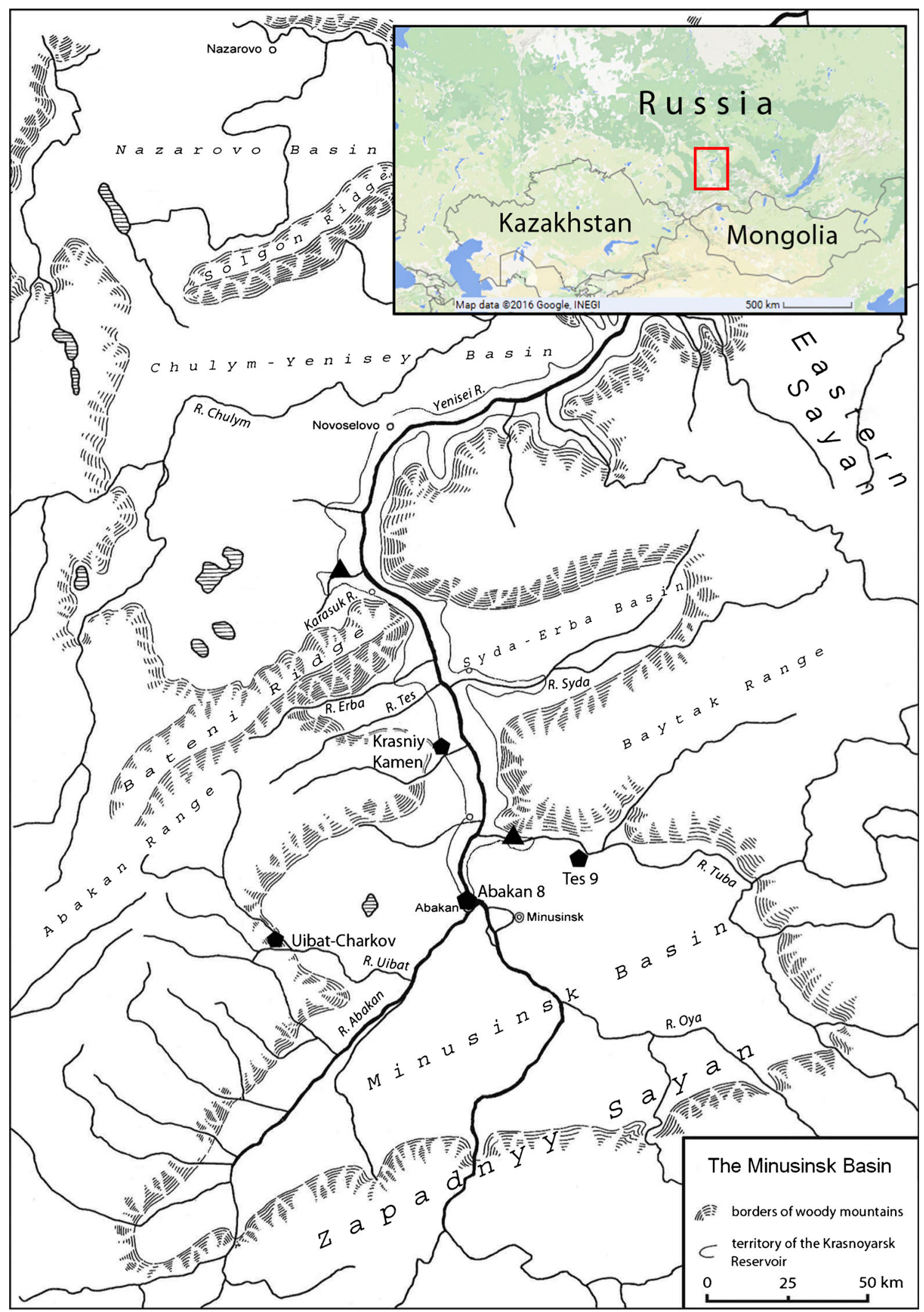

Fig. 1 Location map for the investigated sites (polygons for archaeological samples and triangles for modern fish); adapted from Vadetskaya 1986

Centre for Climate, the Environment and Chronology (Queen's University Belfast). The measurement uncertainty (1sd) of $\delta^{13} \mathrm{C}, \delta^{15} \mathrm{~N}$ and atomic $\mathrm{C}: \mathrm{N}\left(\mathrm{C}: \mathrm{N}_{\mathrm{at}}\right)$ based on $6-10$ replicates of seven archaeological bone collagen samples was 
$0.22,0.15$ and $0.2 \%$, respectively. Sulphur isotopic measurements $\left(\delta^{34} \mathrm{~S}\right)$ were performed in triplicates using a Thermo Delta V IRMS with Thermo Flash 1112 EA in the Stable Isotope Facility of the School of Planning, Architecture and Civil Engineering (Queen's University Belfast), with the analytical precision of \pm 0.4 per mil based on the standards analysed (NBS127 and IAEA-SO6). Results are reported using the delta convention relative to international standards: VPDB for $\delta^{13} \mathrm{C}$, AIR for $\delta^{15} \mathrm{~N}$ and VCDT for $\delta^{34} \mathrm{~S}$ (Krouse and Coplen 1997; Hoefs 2009).

AMS ${ }^{14} \mathrm{C}$ dating was performed in the ${ }^{14} \mathrm{CHRONO}$ Centre. For the AMS ${ }^{14} \mathrm{C}$ measurements, prepared bone collagen and wood samples were sealed under vacuum in quartz tubes with an excess of $\mathrm{CuO}$ and combusted at $850^{\circ} \mathrm{C}$. The $\mathrm{CO}_{2}$ was converted to graphite on an iron catalyst using a zinc reduction method (Slota et al. 1987). Pressed graphite "target" was then measured by 0.5 MV National Electrostatics Compact AMS. The sample ${ }^{14} \mathrm{C} /{ }^{12} \mathrm{C}$ ratio was background corrected and normalised to the HOXII standard (SRM 4990C; National Institute of Standards and Technology). The ${ }^{14} \mathrm{C} /{ }^{12} \mathrm{C}$ ratio, corrected for isotopic fractionation using the AMS-measured $\delta^{13} \mathrm{C}$, is by definition fraction modern $\left(\mathrm{F}^{14} \mathrm{C}\right.$; Reimer et al. 2004). The ${ }^{14} \mathrm{C}$ age and 1 sd were calculated from $\mathrm{F}^{14} \mathrm{C}$ using the Libby half-life (5568 years) following the conventions of Stuiver and Polach (1977). The radiocarbon ages were calibrated using the Calib 7.0 program (Stuiver et al. 2013) and the IntCal13 calibration curve (Reimer et al. 2013).

\section{Calculating the freshwater reservoir offset}

For both archaeological and modern samples, FRO was calculated as a difference in the ${ }^{14} \mathrm{C}$ ages between the "aquatic" (human/fish) and terrestrial (faunal/atmosphere) samples. Atmospheric ${ }^{14} \mathrm{C}$ age and ${ }^{14} \mathrm{C}$ age for the modern fish samples (conventionally given as $>$ modern) were calculated using the following equation: ${ }^{14} \mathrm{C}$ age $=-8033 \ln \mathrm{F}^{14} \mathrm{C} . \mathrm{F}^{14} \mathrm{C}_{\mathrm{atm}}$ for 2007 was taken as a mean of the monthly ${ }^{14} \mathrm{C}_{\text {atm }}$ measurements for 2007 from Levin et al. (2013). ${ }^{14} \mathrm{C}$ age uncertainties for the modern samples were calculated using the following formula: $\sigma^{14} \mathrm{C}=-8033 \times \ln \left(\mathrm{f}^{14} \mathrm{C}+\sigma \mathrm{F}^{14} \mathrm{C}-\left(-8033 \times \ln \left(\mathrm{F}^{14} \mathrm{C}\right)\right)\right.$ for each sample. FRO uncertainty was calculated using $\sigma \mathrm{FRO}=\sqrt{\sigma a^{2}+\sigma b^{2}}$, where $\sigma a$ and $\sigma b$ are ${ }^{14} \mathrm{C}$ age uncertainties for aquatic (human and modern fish) and terrestrial (fauna and atmosphere) samples.

\section{Results}

The majority of bone samples analysed demonstrated excellent collagen preservation with yields ranging between 3.5$19.9 \%$ (van Klinken 1999; Tables 1 and 2). The C: $\mathrm{N}_{\mathrm{at}}$ ratio of the samples varied between 3.1 and 3.5, which is also within the accepted range characterizing well-preserved collagen (DeNiro 1985). At 3.7, the modern fish fell just outside this range, perhaps as a result of the retention of a small amount of lipid. This would not affect the ${ }^{14} \mathrm{C}$ date.

Several observations can be made from the results of radiocarbon dating and stable isotope analysis of the samples. Firstly, in all cases, modern fish demonstrate a reservoir offset, with values differing significantly from $165 \pm 30$ to $757 \pm 31$ ${ }^{14} \mathrm{C}$ years (Table 1 ). The FRO values vary both between different reservoirs (with the tributary Karasuk having a higher offset compared to that of the main Yenisei River, although the latter is represented by only a single sample) and within the reservoir between fish depending on their species (the two pikes having the highest offsets) and age (larger pike being ca. $120{ }^{14} \mathrm{C}$ years "older" than the smaller one). Given the small sample size, the authenticity of these patterns needs to be further verified. Obviously, modern reservoirs in the Minusinsk Basin contain "old" carbon; however, its particular sources remain unclear at the moment.

Secondly, and surprisingly, archaeological humans do not appear to be affected by the FRE (Table 1). With one exception, the human radiocarbon determinations fall within 1sd of those of the associated terrestrial fauna within the same grave. The exception is grave 30 from excavation 5 of the Abakan 8 cemetery, where there is an offset of $154 \pm 54{ }^{14} \mathrm{C}$ years between the human and terrestrial samples. The association of faunal bones and timber with the interred skeleton is quite secure. This burial had been disturbed, however, very "carefully" as skeletons reportedly remained in articulation. The animal bone was located at the feet of the deceased, and its date can be successfully combined (Ward and Wilson 1978) with the date of timber used for the construction of the grave. Admittedly, among the studied sites, Abakan 8 cemetery is the only one located on the shore of the main Yenisei River while other sites are situated near its tributaries. One could suggest geographical variations in the extent of the FRE, with the main Yenisei waters carrying a larger FRE signal; however, it is then unclear why another human from the same cemetery (kurgan 1) is not affected, despite having similar $\delta^{15} \mathrm{~N}$ values, which presumably reflect comparable contributions of high-trophic-level foods, i.e. fish.

For stable nitrogen isotope values, the enrichment of human samples over mean terrestrial fauna $\delta{ }^{15} \mathrm{~N}$ values $(6.6 \pm 2.1 \%$ ) varies between 4.9 and $6.3 \%$ (with an average of $5.7 \pm 1.1 \%$; Fig. 2). The commonly observed humanherbivore nitrogen trophic level increase is usually cited as 3-5 \%o (Minagawa and Wada 1984; Bocherens and Drucker 2003; DeNiro and Schoeniger 1983, etc.), with one recent study proposing that human trophic $\delta{ }^{15} \mathrm{~N}$ enrichment may be as high as $6 \%$ (O'Connell et al. 2012). As such, the human $\delta^{15} \mathrm{~N}$ values in this study are on the borderline of one trophic level offset, and we can only speculate if the diet of humans included fish. Human-herbivore $\delta{ }^{15} \mathrm{~N}$ enrichment has a weak 
Fig. 2 Bone collagen $\delta^{13} \mathrm{C}$ and $\delta^{15} \mathrm{~N}$ values for archaeological human $(n=6)$ and terrestrial herbivore samples $(n=5)$, and modern fish $(n=4)$. For fish samples (lab IDs SS MBF), note that the $\delta^{15} \mathrm{~N}$ values were taken from the sample not subjected to lipid removal; the final $\delta^{13} \mathrm{C}$ value was obtained by taking the carbon isotopic value of the sample which had undergone the lipid removal process and adding $1.5 \%$ for the Suess effect (see Sample Pretreatment section for details)

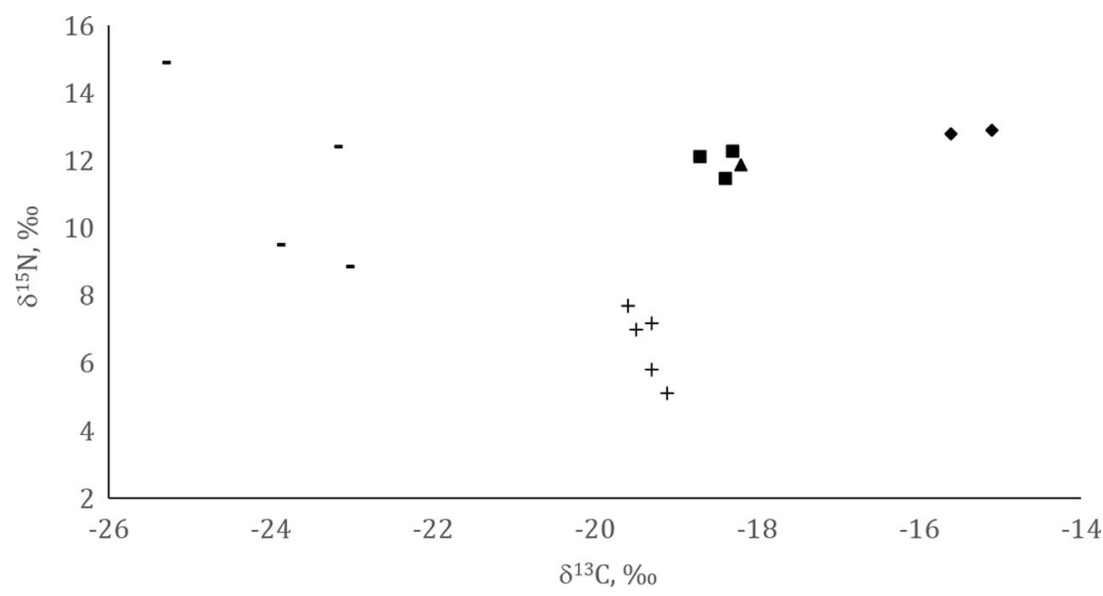

to moderate relationship, but statistically insignificant, with human FRO values $\left(R^{2}=0.45 ; p=0.13\right)$. In fact, more of the associated faunal samples are actually "older" than the humans, though not significantly so, since all of these pairings were statistically the same (Table 2). The exception is again the aforementioned grave 30 at Abakan 8-this human individual is the single case showing a freshwater reservoir offset and it has the highest $\delta^{15} \mathrm{~N}$ enrichment compare to other humans analysed $\left(\Delta \delta^{15} \mathrm{~N}=6.3 \%\right.$ ).

To further investigate the potential impact of aquatic sources in the human diet, stable sulphur isotopes were employed (Richards et al. 2003). The technique has not been routinely used in the region, and, to the best of our knowledge, only one study has been performed in the Eurasian Steppes, namely, at the Late Bronze Age site of Chicha (southwestern Siberia; Privat et al. 2007). The study demonstrated the potential of using $\delta^{34} \mathrm{~S}$ in the area as an additional indicator for freshwater fish consumption, as a pronounced difference between terrestrial and aquatic signals was found. However, the $\delta^{34} \mathrm{~S}$ results for the Minusinsk Basin do not appear to significantly differ from modern fish, archaeological herbivores and humans analysed (in all cases $p>0.05$; Tables 1 and 2; plotted against $\delta^{13} \mathrm{C}$ and $\delta^{15} \mathrm{~N}$ in Fig. 3), and thus cannot contribute additional information on freshwater fish consumption by humans.
Samples of wood were used in the study as an additional terrestrial reference; however, bearing in mind the possibility of "old wood effect" or potential re-use of wood, the results are treated separately from faunal samples. In two of three cases, ${ }^{14} \mathrm{C}$ dates from wood are consistent with those for terrestrial fauna. Only for the kurgan 1 of Abakan 8 cemetery, is the wood sample approximately $160{ }^{14} \mathrm{C}$ years older than associated ovicaprid bone sample. The reason for the older wood age is that, due to the disintegration of the outer wood, the sample was taken from central part of what was apparently originally a very large log.

\section{Discussion and conclusions}

The main observation from this study is that, with a single exception, and despite the FRE values observed for modern fish (from $165 \pm 30$ to $757 \pm 31{ }^{14} \mathrm{C}$ years), archaeological humans do not appear to be significantly affected by the FRE. These are preliminary conclusions, which need to be checked by additional pairs of contemporaneous human and terrestrial samples.

The results for the graves are in agreement with the major previous conclusions on chronology and subsistence of Okunevo and Karasuk populations. The new ${ }^{14} \mathrm{C}$ dates

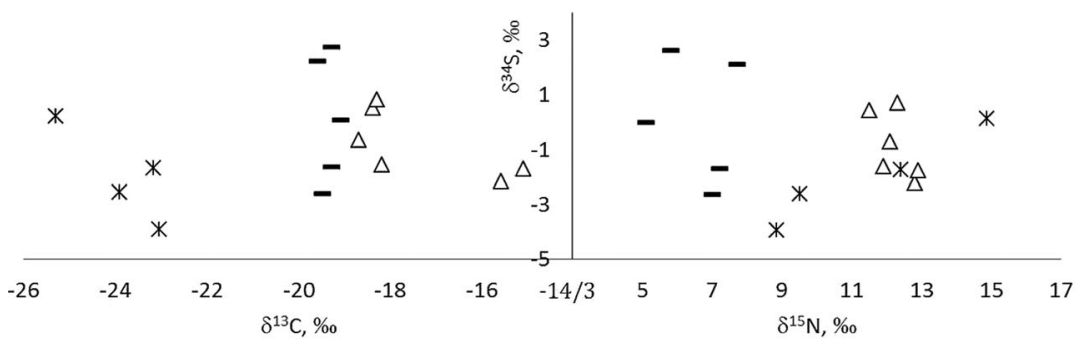

Fig. 3 Bone collagen $\delta^{34} \mathrm{~S}$ values plotted against $\delta^{13} \mathrm{C}$ and $\delta^{15} \mathrm{~N}$ for archaeological human $(n=6)$ and terrestrial herbivore samples $(n=5)$ and modern fish $(n=4)$. For fish samples (lab IDs SS MBF), note that the $\delta^{15} \mathrm{~N}$ values were taken from the sample not subjected to lipid removal; the final $\delta^{13} \mathrm{C}$ value was obtained by taking the carbon isotopic value of the sample which had undergone the lipid removal process and adding $1.5 \%$ for the Suess effect (see Sample Pretreatment section for details). The $\delta^{34} \mathrm{~S}$ values were taken from the sample also not subjected to lipid removal (lab IDs UBA) 
(twenty-sixth to twenty-first century $\mathrm{BC}$ for Okunevo, thirteenth to tenth century BC for Karasuk, and third - early fifth century AD for Tashtyk individuals) support the existing chronology attributing Okunevo culture to twenty-fifth to eighteenth, Karasuk - to the fifteenth to ninth century BC, and Tashtyk - to the third - early fifth century AD (Svyatko et al. 2009; Pankova et al. 2010; Zaitseva et al. 2007).

The isotopic results also correspond well with the previously identified patterns of Bronze to Iron Age subsistence in the region, according to which the diet of the Eneolithic to Middle Bronze Age populations was primarily $\mathrm{C}_{3}$-based and included large proportions of animal protein (and possibly fish), and only from the Late Bronze Age are $\mathrm{C}_{4}$ plants, most likely millet (as no other $\mathrm{C}_{4}$ plants suitable for a dietary staple are known in the area), incorporated into the diet in a systematic, isotopically detectable way (Svyatko et al. 2013). The Late Bronze Age Karasuk individual analysed here does not show $\delta{ }^{13} \mathrm{C}$ enrichment, but this is consistent with previous results showing that this period was highly variable in the contribution of $\mathrm{C}_{4}$ plants, as was the succeeding Early Iron Age Tagar (ibid.). Elevated $\delta^{13} \mathrm{C}$ values of ca. $-15.3 \%$ or the Late Iron Age Tashtyk individuals clearly demonstrate the consumption of millet, confirming that systematic reliance on this crop continued in the region into the Late Iron Age (see also Shishlina et al. 2016). Moreover, we can be reasonably confident in proposing that millet was cultivated in the Basin, since any significant and persistent trade in a staple crop with regions outside the Minusinsk seems unlikely given the distances involved and the long-term average represented by stable isotope measurements of bone collagen. While relatively little archaeobotancial research has been undertaken in the region, millet and barley have been identified at the Early Iron Age Tagar cemeteries of Erbinskaya and Poylovo (Vadetskaya 1986). Although only two associated animal values are presented here, the fact that they are depleted in $\delta$ ${ }^{13} \mathrm{C}$ supports the direct consumption of millet by humans, rather than its use as a fodder crop. This is in keeping with previously reported results for the Late Bronze and Early Iron Ages in the Minusinsk Basin (Murphy et al. 2013; Svyatko et al. 2013).

There are three important outcomes for the mid- to late Holocene archaeology of the Minusinsk Basin from the present paper. The first is that the refined cultural historical sequence present in Svyatko et al. (2009) is likely to remain broadly correct. The second is that there is little reason to doubt the inferred date of ca. $1400 \mathrm{cal} \mathrm{BC}$ for the appearance of millet agriculture in the Basin. Note that this need not be the very first time millet itself appeared in the region, but rather the first evidence for its substantive use, as seen in significantly elevated human $\delta^{13} \mathrm{C}$ values (Svyatko et al. 2013). The third outcome is that our results raise questions concerning the extent to which freshwater fish were in fact consumed by Early Bronze Age to Late Iron Age communities in the Minusinsk
Basin, given that at least some modern fish collected for the Basin's rivers clearly do show a reservoir offset of up to three centuries. However, the effect is highly variable even within the Karasuk River, and seems to have some relationship with fish species, though why this should be the case in this particular context is difficult to understand. This in turn raises a wider issue that extends beyond the Minusinsk Basin, regarding the explanation for high $\delta^{15} \mathrm{~N}$ values in humans, if not as a result of the significant consumption of fish. Further research, for example using $\delta^{2} \mathrm{H}$ measurements on bone collage as another proxy for trophic level (Birchall et al. 2005), may be useful in addressing this question. Single amino acids also hold promise (e.g. Naito et al. 2013). Additional understanding of the spatial and potentially species variability in the FRO in the waters of Basin should also be a priority, alongside further paired archaeological human and faunal radiocarbon measurements.

Acknowledgments This research was supported by the Leverhulme Trust grant RPG-2014-08. We would like to express our thankfulness to Igor P. Lazaretov (Institute for the History of the Material Culture, Russian Academy of Sciences, Saint-Petersburg), Olga V. Kovaleva and Piotr B. Amzarakov (Khakass Research Institute of Language, Literature and History (Abakan)) for providing us with the archaeological samples.

Open Access This article is distributed under the terms of the Creative Commons Attribution 4.0 International License (http:// creativecommons.org/licenses/by/4.0/), which permits unrestricted use, distribution, and reproduction in any medium, provided you give appropriate credit to the original author(s) and the source, provide a link to the Creative Commons license, and indicate if changes were made.

\section{References}

Ascough PL, Cook GT, Church MJ, Dunbar E, Einarsson Á, McGovern TH, Dugmore AJ, Perdikaris S, Hastie H, Friðriksson A, Gestsdóttir $\mathrm{H}$ (2010) Temporal and spatial variations in freshwater $14 \mathrm{C}$ reservoir effects: Lake Myvatn, northern Iceland. Radiocarbon 52:10981112

Birchall J, O'Connell TC, Heaton THE, Hedges REM (2005) Hydrogen isotope ratios in animal body protein reflect trophic level. J Anim Ecol 74(5):877-881

Bligh EG, Dyer WJ (1959) A rapid method of total lipid extraction and purification. Can J Biochem and Phys 37:911-917

Bocherens H, Drucker D (2003) Trophic level isotopic enrichment of carbon and nitrogen in bone collagen: case studies from recent and ancient terrestrial ecosystems. Int J Osteoarchaeol 13:46-53

Brock F, Higham T, Ditchfield P, Ramsey CB (2010) Current pretreatment methods for AMS radiocarbon dating at the Oxford radiocarbon accelerator unit (ORAU. Radiocarbon 52:103-112

Bronk Ramsey C, Higham T, Bowles A, Hedges R (2004) Improvements to the pretreatment of bone at Oxford. Radiocarbon 46:155-163

Brown TA, Nelson DE, Vogel JS, Southon JR (1988) Improved collagen extraction by modified Longin method. Radiocarbon 30:171-177

Cook GT, Bonsall C, Hedges REM, McSweeney K, Boroneant V, Pettitt PB (2001) A freshwater diet-derived 14C reservoir effect at the Stone Age sites in the Iron Gates Gorge. Radiocarbon 43:453-460 
Cook GT, Bonsall C, Hedges REM, McSweeney K, Boroneant V, Bartosiewicz L, Pettitt PB (2002) Problems of dating human bones from the Iron Gates. Antiquity 76:77-85

Culleton BJ (2006) Implications of a freshwater radiocarbon reservoir correction for the timing of late Holocene settlement of the Elk Hills, Kern County, California. J Archaeol Sci 33:1331-1339

Deevey ES Jr, Gross MS, Hutchinson GE, Kraybill HL (1954) The natural $\mathrm{C} 14$ contents of materials from hard-water lakes. P Natl Acad Sci USA 40:285-288

DeNiro MJ (1985) Postmortem preservation and alteration of in vivo bone collagen isotope ratios in relation to palaeodietary reconstruction. Nature 317:806-809

DeNiro MJ, Schoeniger MJ (1983) Stable carbon and nitrogen isotope ratios of bone collagen: variations within individuals, between sexes, and within populations raised on monotonous diets. J Archaeol Sci 10:199-203

Fernandes R, Dreves A, Nadeau MJ, Grootes PM (2013) A freshwater Lake Saga: carbon routing within the aquatic food web of Lake Schwerin. Radiocarbon 55:1102-1113

Fernandes R, Rinne C, Nadeau M-J, Grootes P (2014) Towards the use of radiocarbon as a dietary proxy: establishing a first wide-ranging radiocarbon reservoir effects baseline for Germany. Environ Archaeol. doi:10.1179/1749631414Y.0000000034

Fischer A, Heinemeier J (2003) Freshwater reservoir effect in 14C dates of food residue on pottery. Radiocarbon 45:449-466

Godwin $\mathrm{H}$ (1951) Comments on radiocarbon dating for samples from the British Isles. Am J Sci 249:301-307

Goodfriend G, Flessa K (1997) Radiocarbon reservoir ages in the Gulf of California; roles of upwelling and flow from the Colorado River. Radiocarbon 39:139-148

Gotlib AI, Podolsky M (2008) Sve-mountain constructions of the Minusinsk basin. Elexis print, St. Petersburg 222 p. In Russian

Hoefs J (2009) Stable isotope geochemistry. Springer, Berlin

Ingram BL, Southon JR (1996) Reservoir ages in eastern Pacific coastal and estuarine waters. Radiocarbon 38:571-582

Keaveney EM, Reimer PJ (2012) Understanding the variability in freshwater radiocarbon reservoir offsets: a cautionary tale. J Archaeol Sci 39:1306-1316

Kovalev AA (1997) The cemetery of Verhniy Askiz I, mound 2. In: Okunevskij Sbornik. Cultura. Iskusstvo. Anthropologiya. Polygraphic Centre, St. Petersburg, pp. 80-112 In Russian

Krouse HR, Coplen TB (1997) Reporting of relative sulfur isotope-ratio data. Pure Appl Chem 69:293-295

Kulkova M, Mazurkevich A, Dolbunova E, Regert M, Mazuy A, Nesterov E, Sinai M (2015) Late Neolithic subsistence strategy and reservoir effects in $14 \mathrm{C}$ dating of artifacts at the pile-dwelling site Serteya II (NW Russia. Radiocarbon 57:611-623

Lazaretov IP (1997) Okunevo cemeteries in the valley of the river Uybat. In: Okunevskij Sbornik. Cultura. Iskusstvo. Anthropologiya. Polygraphic Centre, St. Petersburg, pp. 19-64 In Russian

Levin I, Kromer B, Hammer S (2013) Atmospheric Delta (CO2)-C-14 trend in western European background air from 2000 to 2012. Tellus Series B-Chemical and Physical Meteorology 65:20092

Liden K, Takahashi C, Nelson DE (1995) The effects of lipids in stable carbon isotope analysis and the effects of $\mathrm{NaOH}$ treatment on the composition of extracted bone collagen. J Archaeol Sci 22:321-326

Lillie M, Budd C, Potekhina I, Hedges R (2009) The radiocarbon reservoir effect: new evidence from the cemeteries of the middle and lower Dnieper basin, Ukraine. J Archaeol Sci 36:256-264

Lougheed BC, Filipsson HL, Snowball I (2013) Large spatial variations in coastal $14 \mathrm{C}$ reservoir age - a case study from the Baltic Sea. Clim Past 9:1015-1028

Meadows J, Bērzinššc V, Brinkerd U, Lübkea H, Schmölckea U, Staudee A, Zagorskac I, Zarinac G (2016) Dietary freshwater reservoir effects and the radiocarbon ages of prehistoric human bones from Zvejnieki, Latvia. J Archaeol Sci Reports 6:678-689
Minagawa M, Wada E (1984) Stepwise enrichment of $15 \mathrm{~N}$ along food chains: further evidence and the relation between $\mathrm{d} 15 \mathrm{~N}$ and animal age. Geochim Cosmochim Ac 48:1135-1140

Mintenbeck K, Brey T, Jacob U, Knust R, Struck U (2008) How to account for the lipid effect on carbon stable-isotope ratio $\left(\ddot{0}^{13} \mathrm{C}\right)$ : sample treatment effects and model bias. J Fish Biol 72:815-830

Mook WG, Waterbolk HT (1985) Radiocarbon dating. European Science Foundation Handbooks for Archaeologists No. 3, European Science Foundation, Strasbourg

Motuzaite-Matuzeviciute G, Lillie M, Telizhenko S (2015) AMS radiocarbon dating from the Neolithic of eastern Ukraine casts doubts on existing chronologies. Radiocarbon 57:657-664

Murphy EM, Schulting RJ, Beer N, Kasparov A, Pshenitsyna M (2013) Iron Age diet in southern Siberia: information from stable carbon and nitrogen isotopes and dental palaeopathology. J Archaeol Sci 40(5):2547-2560

Naito YI, Chikaraishi Y, Ohkouchi N, Yoneda M (2013) Evaluation of carnivory in inland Jomon hunter-gatherers based on nitrogen isotopic compositions of individual amino acids in bone collagen. $\mathrm{J}$ Archaeol Sci 40:2913-2923

Nomokonova T, Losey RJ, Goriunova OgI, Weber AW (2013) A freshwater old carbon offset in Lake Baikal, Siberia and problems with the radiocarbon dating of archaeological sediments: Evidence from the Sagan-Zaba II site. Quaternary International. The BaikalHokkaido Archaeology Project: Environmental archives, proxies and reconstruction approaches 290-291:110-125

O'Connell TC, Kneale CJ, Tasevska N, Kuhnle GGC (2012) The dietbody offset in human nitrogen isotopic values: a controlled dietary study. Am J Phys Anthropol 149:426-434

Olsen J, Heinemeier J, Lübke H, Lüth F, Terberger T (2010) Dietary habits and freshwater reservoir effects in bones from a Neolithic NE German cemetery. Radiocarbon 52:635-644

Pankova SV, Vasiliev SS, Dergachev VA, Zaitseva GI (2010) Radiocarbon dating of Oglachty grave using a wiggle matching method. Achaeology, Ethnology and Anthropology of Eurasia 38(2):46-56

Privat KL, O'Connell TC, Hedges REM (2007) The distinction between freshwater- and terrestrial-based diets: methodological concerns and archaeological applications of sulphur stable isotope analysis. J Archaeol Sci 34:1197-1204

Reimer PJ, Brown TA, Reimer RW (2004) Discussion: reporting and calibration of post-bomb C-14 data. Radiocarbon 46:1299-1304

Reimer PJ, Bard E, Bayliss A, Beck JW, Blackwell PG, Bronk Ramsey C, Buck CE, Cheng H, Edwards RL, Friedrich M, Grootes PM, Guilderson TP, Haflidason H, Hajdas I, Hatté C, Heaton TJ, Hoffmann DL, Hogg AG, Hughen KA, Kaiser KF, Kromer B, Manning SW, Niu M, Reimer RW, Richards DA, Scott EM, Southon JR, Staff RA, Turney CSM, van der Plicht J (2013) IntCal13 and Marine13 radiocarbon age calibration curves 0-50, 000 Years cal BP. Radiocarbon 55:1869-1887

Richards MP, Fuller BT, Sponheimer M, Robinson T, Ayliffee L (2003) Sulphur isotopes in palaeodietary studies: a review and results from a controlled feeding experiment. Int J Osteoarchaeol 13:37-45

Schulting R, Ramsey CB, Bazaliiskii VI, Goriunova OI, Weber A (2014) Freshwater reservoir offsets investigated through paired humanfaunal $14 \mathrm{C}$ dating and stable carbon and nitrogen isotope analysis at Lake Baikal, Siberia. Radiocarbon 56:991-1008

Schulting RJ, Bronk Ramsey C, Bazaliiskii VI, Weber A (2015) Highly variable freshwater reservoir effects found along the upper Lena watershed, Cis-Baikal, southeast Siberia. Radiocarbon 57:581-593

Shishlina NI, Plicht JVD, Hedges REM, Zazovskaya EP, Sevastyanov VS, Chichagova OA (2007) The catacomb cultures of the northwest Caspian Steppe: 14C chronology, reservoir effect, and palaeodiet. Radiocarbon 49:713-726

Shishlina NI, Zazovskaya EP, van der Plicht J, Hedges REM, Sevastyanov VS, Chichagova OA (2009) Paleoecology, 
subsistence, and 14C chronology of the Eurasian Caspian Steppe bronze age. Radiocarbon 51:481-499

Shishlina N, Zazovskaya E, van der Plicht J, Sevastyanov EV (2012) Isotopes, plants, and reservoir effects: case study from the Caspian Steppe Bronze Age. Radiocarbon 54:749-760

Shishlina N, Sevastyanov V, Zazovskaya E, van der Plicht J (2014) Reservoir effect of archaeological samples from steppe Bronze Age cultures in southern Russia. Radiocarbon 56:767-778

Shishlina N, Pankova S, Sevastyanov V, Kuznetsova O, Demidenko Y (2016) Pastoralists and mobility in the Oglakhty cemetery of southern Siberia: new evidence from stable isotopes. Antiquity 90(351): 679-694

Slota JP, Jull A, Linick T, Toolin L (1987) Preparation of small samples for $14 \mathrm{C}$ accelerator targets by catalytic reduction of $\mathrm{CO}$. Radiocarbon 44:167-180

Sotiropoulos MA, Tonn WM, Wassenaar LI (2004) Effects of lipid extraction on stable carbon and nitrogen isotope analyses of fish tissues: potential consequences for food web studies. Ecol Freshw Fish 13:155-160

Stuiver M, Polach HA (1977) Discussion: reporting of 14C data. Radiocarbon 19:355-363

Stuiver M, Reimer PJ, Reimer RW (2013) CALIB 7.0. (WWW program and documentation). URL: http://radiocarbon.pa.qub.ac. uk/calib/calib.htm

Sveinbjörnsdóttir Á, Heinemeier J, Arnorsson S (1995) Origin of 14C in Icelandic groundwater. Radiocarbon 37:551-565

Svyatko SV, Mallory JP, Murphy EM, Polyakov AV, Reimer PJ, Schulting RJ (2009) New radiocarbon dates and a review of the chronology of prehistoric populations from the Minusinsk Basin, southern Siberia, Russia. Radiocarbon 51:243-273
Svyatko SV, Schulting RJ, Mallory J, Murphy EM, Reimer PJ, Khartanovich VI, Chistov YK, Sablin MV (2013) Stable isotope dietary analysis of prehistoric populations from the Minusinsk Basin, southern Siberia, Russia: a new chronological framework for the introduction of millet to the eastern Eurasian steppe. J Archaeol Sci 40:3936-3945

Svyatko SV, Mertz IV, Reimer PJ (2015) Freshwater reservoir effect on redating of Eurasian Steppe cultures: first results for Eneolithic and Early Bronze Age Northeast Kazakhstan. Radiocarbon 57:625-644

Tieszen LL, Fagre T (1993) Carbon isotopic variability in modern and archaeological maize. J Archaeol Sci 20:25-40

Vadetskaya EB (1986) Archaeological sites in the middle Yenisei River steppes. Nauka Press, Leningrad 180 p. In Russian

Vadetskaya EB, Poselyanin AI (2015) Tashtyk burial-memorial complex of Beliy Yar 3. Khakas Book Publishers, Abakan 148 p. In Russian

Vadetskaya EB, Leontev NV, Maksimenkov GA (1980) Sites of the Okunevo culture. Nauka Press, Leningrad 148 p. In Russian

van Klinken GJ (1999) Bone collagen quality indicators for palaeodietary and radiocarbon measurements. J Archaeol Sci 26:687-695

Ward GK, Wilson SR (1978) Procedures for comparing and combining radiocarbon age determinations: a critique. Archaeometry 20:19-31

Wood RE, Higham TFG, Buzilhova A, Suvorov A, Heinemeier J, Olsen J (2013) Freshwater radiocarbon reservoir effects at the burial ground of Minino, Northwest Russia. Radiocarbon 55:163-177

Zaitseva GI, Sementsov AA, Lebedeva LM, Pankova SV, Vasiliev SS, Dergachev VA, Jünger H, Sonninen E (2007) New data on the chronology of the site of Oglakhty VI. Radiouglerod v arheologicheskih i paleoekologicheskih issledovaniyah. Materials of the conference dedicated to the 50th anniversary of radiocarbon laboratory of the Institute for the History of Material Culture RAS. St. Petersburg. $p$ 300-306. In Russian. 